\title{
The Obstacle Factors of the Service Rural Grassroots Party Organization and the Measures Analysis - Based on the Angle of the Mass View of Marxism
}

\author{
Yongjiu Shu ${ }^{1} \&$ Rui Wang ${ }^{1}$ \\ ${ }^{1}$ Political College, Sichuan Agriculture University, Ya'an, China \\ Correspondence: Yongjiu Shu, Political College, Sichuan Agriculture University, Ya'an 625014, Sichuan, China. \\ Tel: 86-1-305-656-1549. E-mail: shuyongjiu@126.com
}

Received: December 10, 2012 Accepted: December 14, 2012 Online Published: February 26, 2013

doi:10.5539/jpl.v6n1p80 URL: http://dx.doi.org/10.5539/jpl.v6n1p80

This paper is the research result of philosophical and social science planning project in the Sichuan Province (SC10W209), and the research result of rural development and research center project in Sichuan Province (CR1126).

\begin{abstract}
The mass view is the core and the soul of the Marxist historical materialism, which is also the basic point of Marxism sinicization. From the perspective of the mass view of Marxism, anglicising the barrier factors such as service environment problems, service consciousness, and service system obstacles during our construction of service-oriented grass-roots party. What's more, through enhancing service consciousness, raising the service ability, constructing the service platform, and establishing long-term service mechanism,etc to solve the obstacles, which have great theoretical significance and practical significance in insisting on and developing mass views and building the socialist harmonious society.
\end{abstract}

Keywords: mass notion of Marxism, services-oriented, rural grass-root party organization, barrier factors

The mass viewpoint is the core and the soul of historical materialism, which is also the essential view of the sinicization of Marxism. The mass viewpoint of Marxist emphasizes that the masses are not only the creators of the material wealth and the spiritual wealth, but also the subjects and the desire force of social change and its progress. If the Communist Party of China would to promote the progress of history, it should mobilize the enthusiasm of the most numerous people and represent the fundamental interests which would be shown on carrying out the purpose of serving the people wholeheartedly. Mao Tse-tung, the founder of the People's Republic of China, once explicitly pointed out that the one of the prominent signs which our party is different from other political party is getting the most closely related with the mass of people and serves the people wholeheartedly which is also a notable characteristic of Marxism party and the biggest political advantage of CPC. Serviceability is not only the natural attribute of party organization, but also a necessary attribute to development. Whether a party sizes state power or not, consolidates its ruling position or not, its key is whether the party can gain the universal upholding and support of the masses or not, has a firm class base and widespread mass base or not, ruling party build itself to service-oriented political parties.

The service-oriented rural grassroots party organization uphold the CPC' purpose, and penetrate "service" into every aspect of the construction of the party. Materialistic dialectics show us that the emergence and development of new things is not easy. During the developing process of the rural grassroots party organization, it would face tremendous barriers. Only we face squarely and find ways to solve them can we make progress.

\section{The Barriers of Constructing the Service-oriented Rural Grassroots Party Organization}

\subsection{Service Environment Problems}

During the planned economy period, the rural grassroots party organization directly controlled the economic and political resources, mobilized and organized operations and had been in charge of specific economic development and social affairs, so it was formed close and simple relations with peasantry. However, in the condition of developing socialist market economy, the rural management was reformed continuously, and the 
relationship between the rural grassroots party organization and the peasantry has deep changed. The rural grassroots party organization has never represent the people's interests as the corpus position during the produces to conduct, and it also has never unify management and benefit distribution. Undoubtedly it will be a challenge in the changing process that how to achieve, maintain and develop the benefit of the peasantry which would form internal and close interest relationship among the new rural construction, the party organization and the peasantry.

Facing the autonomy of the production and operation activities of the pleasantry enhance day by day, facing the multi-sector, geographical and diversified forms of association and facing the rural labor who stream frequently in the industry and areas and the most peasants who hunt job and engage remote from the land, we should study and research that how to extend the tentacles, how to strengthen the management of the floating labor and to organize the peasantry carefully.

\subsection{Service System Problems}

Since the reform and opening-up, it is the villager autonomy that our party leads millions of farmers to create a way suiting to national condition and advancing rural grassroots democratic politics. However, we must face up to the matter that there exist contradiction and collision between villagers'self government and township-level government. From a legal perspective, relationship between town government which is as the most basic level political organization and the villager autonomous organization is guided by the guidance, not the leading and the led. Whereas in actual operation, the township party committee and government through the party organization to permeate and extend the power of the township in the village, intervening even impeding the promotance of the villager autonomy. We should know that the functions of autonomy of villager committee is given by "The Organic Law of the villagers Committees of the People's Republic of China" and a nationality township or a town shall guide, support and help the villagers committees in their work, but may not interfere with the affairs that lawfully fall within the scope of the villagers self-government. Therefore, the rural party organization needs exploring in depth that how to lead villager committee and the masses effectively and how to enlarge the power foundation of the party.

\subsection{Service Consciousness Problems}

Our country is going through economic transformation, pragmatism, utilitarianism etc, so it makes people confused how to deal with the personal interests, collective interests and national interest. The service consciousness influences service ability indirectly and the service capability depends on the quality of the party members whose abilities effect the capability of governing, developing economy and advancing the society more harmonious.

Some village party organizations think that emphasizing the construction of the party is their work, not the rural committee's matter, leading to the work effect is not obvious and formalistic. The thinking of some rural party member lags behind reality and their pioneer spirit. Some party members take many positions with low pay which lead them lack of motivation and initiative. Some villager leaders are aging and their education level is poor, so they couldn't develop example in the work which results in weaking the party organization, the executive power and fighting capacity. So they cannot accurately grasp the masses' necessity and expectation, and are lack of skills and methods to do well in the mass work in the new situation. What's more, they are unable to be adept the methods in promoting the development of rural work such as elicitation of education, democratic consultations, demonstration guidance and providing better service.

\section{The Countermeasures of Eliminating the Obstacles during the Construction of Service-oriented Rural Grass-roots Party Organization}

The generation of new things is not perfect and needs to be improved in the process. To really solve a problem, first of all is to excavate the root which is the fundamental way to solve the problem. Although obstacles during the construction of the service-oriented rural grass-roots party organization are various, the thin viewpoint of the masses is essential. To solve these obstacles, we should focus on changing ideas and re-examine the historical position and realistic significance of the masses view of Marxism and make it guiding the new rural construction and the harmonious society construction.

\subsection{Clear Orientation, Strengthening Ideological Education and Service Consciousness}

We should adhere the fundamental principle that serves the people wholeheartedly to practice, and take the fundamental interests of the majority of the people as the starting point and the foothold of party work. The view of serving the people wholeheartedly is not only revealing the party's mass view purpose but also the concrete embodiment of the mass viewpoint of the party's nature and purpose. Our party must adhere the masses view of 
Marxism and insist on the purpose of serving the people wholeheartedly and put the realization and safeguard the fundamental interests of the majority of the people as the party's theory, line, principles and policies that all work's rationale. The party branch is in the core position of the leadership. It is the CPC's effective management experience of the countryside that organizes the millions of farmers through the grassroots party organization. In the new historical conditions, the party branch only plays the role as the core of leadership which can effectively integrate the rural political and economic order. Rural cadres represent our party. The qualities of the rural cadres are directly related to the relationship between the party and the masses. To satisfy the interests of the masses desire the fundamental way is that our party should expand the mass base in the rural areas.

The rural grassroots party organization should adapt for the historical change to change the methods and to change the administrative means which has been adopted for a long time. Through the economic way, the democratic way, the legal way as well as the ideological way to organize and solidify the masses, we can create a good environment and strong guarantee organization for the rural economic construction and social development What's more, through the application of market mechanism to guide farmers to cater the market, optimize structure, improve quality, pay attention to the benefit and improve the party to the rural work leadership in order to optimize the activities in the rural development. The rural grass roots party organization guides the villagers to cherish and exercise their democratic rights and train all the villagers correct democratic consciousness and the ability of political participation and consultation, which could form deep democratic culture and atmosphere.

\subsection{Innovation, Improving Methods and the Service Abilities}

The rural party organization's system and mechanism mainly includes the administration system, organizational life system, the cadre system, the decision making mechanism, the power restriction and supervision mechanism, etc. Any structure always has this or that kind of functions, and structure is the carrier of realizing the function. The arrangement of combination effect including the setting of the structure of the rural grassroots party organization, the structure of the party members and the party member cadre team as well as the ability elements directly influence the degree of the realization of the function of the new rural construction of rural grassroots party organization which demand the rural grassroots party organization leadership transiting from the traditional "taxation", "pay distribution", "charge" to investigation and study, scientific planning model demonstration up as soon as possible.

The innovation and perfect of the grassroots democracy management system, the enlargement of the scope of the villagers' self-government, and safeguard farmers having more practical democratic rights require rural grassroots organizations to improve the style of leadership, to develop the inner-party grassroots democracy which could drive the countryside grassroots democracy. That also demands straightening the relationship between the party branch and the village committee in the system in order to establish effective job specification. Through the ways such as lectures, theory discussion, going to visit, we innovate the party's organization system; through depending on the different post, personal ability etc, we divide responsibility regional to innovate party member objective management; At the same time, through the establishment of scientific selection mechanism, we input the talents to the ruling team to improve the service ability.

In the cadre system, we should treat the theoretical accomplishment and learning ability as an important measure to select and appoint the leading cadres especially leading and promoting new rural construction of the selection, so those who have wide knowledge of natural science and social science knowledge comprehensive talents, such as college students village official, and the three assistances and one relief project personnel to leadership positions. In adhering basic conditions such as the strong party spirit conception, high political quality, and the higher masses prestige, at the same time, we treat the entrepreneurial innovation ability, the leadership of science development capability, and the ability to improve the peasants' income as rigid standard and establish a sufficient number, quality excellent village-level reserve cadres gradually.

\subsection{Multilateral Participation, Strengthening Service Function, and Constructing Service Platform}

System theory thought that the organization's survival, development and growth have very big concern with the openness of the system. Organization itself is a system which is consisted of several subsystems structure internal. Service-oriented grassroots party construction itself is a system development process, which is not only from the construction of the party itself, also can not get away from its surroundings other related organization participation.

Our service of rural grassroots party organization should set up service network which the party members could tie with the masses, members of the party branches, contact party members, and set up the party members' service center for party members and the masses to provide organization affiliated relationship and switching, policy consultation, skills training, remote education, information management and many other services. What's 
more, our service of rural grassroots party organization should pay attention to democratic political rights of the party members and the masses. From the villagers' vital interests and new countryside actual situation, the service rural grassroots party organization should communicate with the masses, listen to the opinions of the masses, go deep among the masses and be the one with the masses.

2.4 The Joint of the Party and the Masses, Strengthening Supervision and Security and Establishing the Long-term Service Mechanism

Practicing the masses view of Marxism, the service rural grassroots party organization should form a good system and mechanism. One is to tell the crowd the decision-making items frankly which has closely related with the people's vital interest, and through the publicity, hearing, and other forms to let people participate and express their opinions and suggestions. The second is to relate the hook supporting system closely and deeply in the village and establish the support system in order to make the crowds out of troubles as soon as possible. What's else, the service rural grassroots party organization obtains from the thought, style, organization and system to strengthen self-construction of the grassroots party organization, so it could provide the assurance of organization and guarantee funds; The service of rural grassroots party organization should establish the incentive mechanism whose starting point is to inspire and mobilize the party work enthusiasm and the initiative. Especially, it is to further establish and improve punishing and preventing corruption of the work through education, system and supervision system to reshape grass-roots party cadre's image of being honest and clean and through good self image to get their authority.

\section{Results}

\subsection{Building Service Grass-roots Party Organization Is an Inevitable Election}

The fifth session of the 16th central committee of the CPC has been promoting the historical task of building the new socialist countryside, and the 18th national congress of communist party of china put forward the aim to building a moderately prosperous society in all respects clearly. Rural grass-roots party organizations, as the forefront in the construction of the new socialist countryside, have unshrinkable responsibility for service druing the major historical tasks which are benefit to the hundreds of millions of farmers. At present, the contradiction between the rapid growth of social public demand and the serious omission of the public service is outstanding. That service-oriented government, which main part is social management and public service, become the internal demand of the building new countryside. Meanwhile, the construction of rural grassroots service-oriented party organization has guidance function and demonstrative effect to the construction of service-oriented government. Therefore, according to the theory of marxism party function change, it has very important practical significance to be based on the realistic predicament of the construction of service-oriented grassroots party organizations, to examine the problems and factors during the construction of rural grassroots party organization and to search the barriers of building the rural service-oriented grass roots party organizations during the construction of the new countryside.

\subsection{That Building Service-oriented Grass-roots Party Organizations must adhere to the Masses View of Marxism, and adhere to the Purpose of Serving the People Whole-heartedly}

The Communist Party of China's basic purpose is to serve the people wholeheartedly. Serving the people must adhere to the scientific theory as guidance, adhere the viewpoint of the masses in practice, follow the mass line, and constantly overcome the obstacles in the service environment, service system and service consciousness, so that the rural grassroots party organization could become the strong fighting bastion which can give impetus to the development, serve the people, condense public support and promote social harmony.

To sum up, building up a service-oriented grassroots party organization is the trend of The Times, so we firmly believe that adhering to the masses view of Marxism and the aim of serving the people, and service-oriented grassroots party construction will blossom everywhere. The new rural construction of China will produce more rich fruit and build the harmonious society.

\section{References}

Backer, L. C. (2011). Party, People, Government and State: on constitutional values and the legitimacy of the Chinese state-party rule of law system. Boston University International Law Journal, 30.

Croissant, A. V. P. (2012). Party system types and party system institutionalization: Comparing new democracies in East and Southeast Asia. Party Politics, 18.

Guo, X. G. (2011). Some Thought on Innovation of Systems and Mechanisms of the Rural Grassroots Party Construction. Xuexi Luntan (study forum). 
Liu, Z. H. (2004). The Governing Rules of the Communist Party of China. Shanghai:SanLian Shudian.

Mao, T. T. (1991). Selected Works of Mao Tse-tung Vol.III. Beijing: People's Publishing House.

The organization department of CPC of Feng Hua, Zhe Jiang province. (2011). The exploration of building a service-oriented grass-roots party organization. Dangjian Yanjiu (party-building research), 3.

Wang, C. J. (2008). The Almighty Party Change into the Service-Oriented Party. Zhongguo Gaige (China's Reform).

Zhang, Y. (2012). The Sinicization of the Masses View of Marxism and its Practical Significance. Mao Zedong Deng Xiaoping Lilun Yanjiu (Studies of Mao Tse-tung Thought and Deng Xiaoping Theory), 2. 